\title{
Evidence of myocardial injury in horses with colic
}

\author{
Priynka Rani ${ }^{1}$, Raj S. Singh ${ }^{2 *}$, Swaran Singh ${ }^{1}$, and Kuldip Gupta ${ }^{3}$ \\ ${ }^{1}$ Department of Veterinary Medicine, Guru Angad Dev Veterinary and Animal Sciences University, Ludhiana, \\ Punjab, India \\ ${ }^{2}$ Department of Teaching Veterinary Clinical Complex, Guru Angad Dev Veterinary and Animal Sciences University, \\ Ludhiana, Punjab, India \\ ${ }^{3}$ Department of Veterinary Pathology, Guru Angad Dev Veterinary and Animal Sciences University, Ludhiana, \\ Punjab, India
}

RANI, P., R. S. SINGH, S. SINGH, K GUPTA: Evidence of myocardial injury in horses with colic. Vet. arhiv 91, 565-574, 2021.

\section{ABSTRACT}

Development of endotoxemia associated with gastrointestinal injury is often observed in horses with colic. Such patients are likely to develop cardiovascular complications associated with endotoxemia, including myocardial injury. Few studies have investigated the prevalence of myocardial injury in horses with colic. Cardiac biomarkers such as cardiac troponin I (cTnI) have been extensively used in human and veterinary medicine for diagnosis of myocardial injury. The aim of the present study was to investigate the occurrence of myocardial injury in horses with colic by measuring serum cTnI concentrations. Myocardial tissue samples from non-surviving horses were also subjected to histopathological evaluation. Serum cTnI concentration was measured in 10 healthy horses and 39 horses with colic. Associations were determined of $\mathrm{cTnI}$ concentration, and variables such as health status (healthy and horses with colic), type of colic (inflammatory, impaction, and unknown), the severity of abdominal pain (mild, moderate and severe), and clinical outcome (survivor to discharge and non-survivor). As compared with healthy horses, cTnI concentrations were significantly elevated in horses with colic $(\mathrm{P}=0.004)$. In horses with colic, an abnormal cTnI concentration was significantly associated with inflammatory colic $(\mathrm{P}<0.05)$, severe abdominal pain $(\mathrm{P}<0.01)$, and negative clinical outcome $(\mathrm{P}<0.0001)$. Further, histopathological evaluation of the myocardial muscles revealed a varying degree of myocardial degeneration and necrosis. The present study suggested that horses with severe colic and increased cTnI levels are more likely to develop myocardial injury. Elevated levels of cTnI may also be indicative of poor prognosis in horses with severe colic.

Key words: colic; equine; myocardium; cardiac troponin I; histopathology

\section{Introduction}

Colic, a clinical sign referred to abdominal pain, is a major cause of mortality and morbidity in horses, and thus is a significant contributing factor to economic losses to the equine industry worldwide (EGENVAet al., 2006). It is caused by a number of diseases affecting the abdominal organs, but gastrointestinal disease is the most common cause for horses showing clinical signs of colic

\footnotetext{
*Corresponding author:

Assoc. Prof. Raj Sukhbir Singh, PhD, Department of Teaching Veterinary Clinical Complex, College of Veterinary Science, Guru Angad Dev Veterinary and Animal Sciences University, Ludhiana - 141 004, Punjab, India, Phone: +91 1612414007 ; Fax: +91 161 2400 822; E-mail: rsbs_66@rediffmail.com
} 
(CURTIS et al., 2015). The clinical outcome or prognosis of equine colic patients largely depends on the severity of the observable clinical signs, and the degree of alterations in the physical and laboratory examination findings (ROBERTSON and SANCHEZ, 2010; RANI et al., 2018). Horses with severe colic often develop endotoxemia as a result of absorption of endotoxins into the systemic circulation from the lumen of the gastrointestinal tract (GIT), secondary to intestinal ischemia and necrosis (KING and GERRING, 1988; SENIOR et al., 2011) Furthermore, due to the development of endotoxemia and sepsis, colic patients are more susceptible to myocardial injury (HALLOWELL and BOWEN, 2007; NOSTELL et al., 2012).

Cardiac biomarkers, such as lactate dehydrogenase isoenzymes, aspartate transaminase and creatine kinase myocardial-band(CK-MB), have long been used to detect cardiac injury in humans and animal species with variable results (DIANA et al., 2007; NOSTELL and HAGGSTROM, 2008; ALSAAD and NORI, 2010). Cardiac troponin I (cTnI), a sensitive and specific biomarker of acute myocardial injury in human patients, is released into the blood from cardiac myocytes in response to injury (BABUIN and JAFFE, 2005). In spite of acute and/or chronic skeletal muscle injury, cTnI levels are not elevated unless there is simultaneous myocardial injury(ADAMS et al., 1993). Moreover, cTnI persists in the blood circulation for extended periods, allowing diagnosis days after a transient myocardial injury (COLLINSON et al., 2001; RAJAPPA and SHARMA, 2005). The elevation in cTnI has been associated with several localized cardiac or systemic events, such as hypoxiaischemia, inflammation, toxicoses and trauma (FENNELL et al., 2009).

Human cTnI assays have been validated for use in horses (RISHNIW and SIMPSON, 2005; KRAUS et al., 2010), and several studies have demonstrated elevated levels of cTnI in horses suffering from various types of clinical conditions (NATH et al., 2012a; RADCLIFFE et al., 2012; DIAZ et al., 2014; ROSSI et al., 2014). In a recent study, about $53 \%$ of equine colic patients had an abnormal cTnI concentration at one time point, and this was correlated with the occurrence of ventricular dysrhythmia, surgical intervention and non-survivability (DIAZ et al., 2014). In contrast, no association was found between the mean cTnI and clinical outcome in horses undergoing emergency abdominal surgery (RADCLIFFE et al., 2012). In spite of the differences in the results of these studies, its improved sensitivity, specificity, and longer halflife make cTnI a promising candidate for detection of myocardial injury in critically ill horses (ROSSI et al., 2014).

The aim of the present study was to investigate the occurrence of myocardial injury in horses suffering from colic by measuring serum cTnI concentrations.

\section{Materials and methods}

Animal selection. The criteria for inclusion of horses in the study were: the presence of clinical signs suggestive of colic (looking at the flank, pawing, rolling, and sweating), diagnosis of GIT disease, and collection of a blood sample at admission. Thirty-nine equine colic patients (colic group) with complete available data were enrolled in the study. Clinical examination of the colic patients was performed by one of the authors and the clinician on duty at the time of presentation. Parameters recorded at admission included age, sex, breed, appetite, mentation, body posture, heart rate (HR), respiratory rate (RR), color of mucous membrane, capillary refill time (CRT), and rectal temperature. The severity of abdominal pain was scored and classified as mild, moderate or severe, on the basis of behavior, response to the surrounding, and vital physiological parameters of colic patient (VAN LOON et al., 2010).

Ten healthy horses (healthy group), kept at the University horse riding school, were also enrolled as control. Clinical examination of these horses was performed to ensure that they were clinically healthy.

The present study was conducted at the large animal clinics of the University and was approved by the Institutional Animal Ethics Committee.

Sample collection and estimation. Blood samples were collected from all the enrolled horses (at the time of admission for colic patients) via jugular venipuncture. Following collection, blood 
samples were centrifuged at 3,400 rpm for 15 minutes to obtain serum samples. Serum samples were aliquoted into $2 \mathrm{~mL}$ micro-centrifuge tubes and stored at $-20{ }^{\circ} \mathrm{C}$ until further analysis. Frozen serum samples were thawed to room temperature before estimation of cTnI.

Cardiac troponin I $(\mathrm{ng} / \mathrm{mL})$ was measured with the help of a commercially available enzyme immunoassay system (Troponin ELISA, Calbiotech Inc., CA). Values of cTnI below the limit of detection were assigned a value of $0.001 \mathrm{ng} / \mathrm{mL}$. The troponin nucleotide and amino-acid sequence is highly conserved across mammals, therefore human assays can be used to detect equine cTnI (DIANA et al., 2007, NATH et al., 2012a).

The horses with colic were treated medically or surgically as per the standard protocol used in clinics for treatment of equine colic patients. The outcome of each case was recorded (survivor to discharge or non-survivor). Necropsy was performed on horses that died, if owner consent was given. Samples of the left and right atrial and ventricular free walls were collected in $10 \%$ neutral buffered formalin, processed, and embedded in paraffin wax. Cut sections of approximately $5 \mu \mathrm{m}$ were stained using $\mathrm{H} \& \mathrm{E}$ and examined microscopically for histopathological evaluation by an experienced pathologist who had no knowledge of the results of the physical examinations and diagnostic tests that had been performed.

Statistical analysis. Data were analyzed using Minitab statistical software (Minitab Inc., Version 14.2). Descriptive statistics were calculated for continuous and categorical variables and presented as median (range), frequencies and proportions. The variables included in the study were: health status (healthy or colic groups), type of colic (inflammatory, impaction, or 'unknown'), severity of abdominal pain (mild, moderate, or severe), and clinical outcome (survivor to discharge or nonsurvivor). Non-parametric tests (Kruskal-Wallis equality-of-populations rank testand Mann-Whitney $\mathrm{U}$ test) were used to examine the significance of differences in cTnI and vital parameters between the variables considered in this study. Additionally, cases were grouped according to whether serum cTnI concentration at the time of admission was abnormal (cTnI $>0.1 \mathrm{ng} / \mathrm{mL}$ ), and Fisher's exact test was used to examine the association between these groups and health status and clinical outcome. Spearman rank-order correlation (rho) analysis was used to study relationships between absolute cTnI concentration and HR, CRT and RR at admission. The differences are considered significant at $\mathrm{P}<0.05$.

\section{Results}

The healthy group consisted of all Thoroughbred horses, of which $9(90 \%)$ were males, and the median age was 12.5 years (range 6-25 years). Horses in the colic group $(n=39)$ consisted of $13(33.3 \%)$ Thoroughbred, 22 (56.4\%) Marwari, and 4 (10.3\%) mixed breed horses. There were 14 (35.9\%) male horses and 25 (64.1\%) female horses. Their ages ranged from 1.5-14 years (median 6 years), with the majority $(82 \%)$ below 10 years of age.

Sixteen (41\%) horses were diagnosed with inflammatory colic (consisting of enterocolitis, strangulation, and peritonitis), 13 (33.4\%) with impaction colic, and in $10(25.6 \%)$ horses no apparent diagnosis could be made on clinical examination (classified as 'unknown'). On the basis of the composite pain scale scoring criteria, $14(35.9 \%)$ horses had mild pain, $12(30.7 \%)$ had moderate pain, and $13(33.3 \%)$ had severe pain.

Thirty-eight horses were treated medically, and one was referred for abdominal surgery. A total of $13(33.3 \%)$ horses (including 12 treated medically, and one undergoing abdominal surgery for small intestinal strangulation) did not survive in this study. None of the horses was euthanized due to poor prognosis or economic considerations. Of the 13 non-survivors, 9 had inflammatory colic and 4 had impaction colic. Necropsy was not possible in 9 non-survivors for various reasons, such as the owner's refusal of post-mortem, and putrefaction of the carcass. At necropsy, five horses were diagnosed with inflammatory lesions (two had strangulating lesions involving the small intestine and the colon; two had generalized edema and congestion of the intestinal mucosa; and one had a peritonitis) and three were diagnosed with impaction/obstructive lesions (one with an enterolith; and two with impactions, one each involving the right dorsal colon and the cecum). 
Table 1. Serum cardiac troponin I concentrations according to health status, type of colic, severity of pain and clinical outcome

\begin{tabular}{|l|c|c|c|}
\hline \multirow{2}{*}{ Variable } & No. of horses & Cardiac troponin I (ng/mL) \\
\hline \multirow{3}{*}{ Health status } & Healthy group & 10 & $0.001^{\mathrm{a}}(0.001-0.02)$ \\
\cline { 2 - 4 } & Colic group & 39 & $0.1^{\mathrm{b}}(0.001-4.5)$ \\
\hline \multirow{3}{*}{ Type of colic } & Inflammatory & 16 & $1.85^{\mathrm{a}}(0.001-4.5)$ \\
\cline { 2 - 4 } & Impaction & 13 & $0.02^{\mathrm{b}}(0.001-2.44)$ \\
\cline { 2 - 4 } & Unknown & 10 & $0.004^{\mathrm{b}}(0.001-0.82)$ \\
\hline \multirow{3}{*}{ Severity of pain } & Mild & 14 & $0^{\mathrm{a}}(0.001-0.23)$ \\
\cline { 2 - 4 } & Moderate & 12 & $0.07^{\mathrm{a}}(0.001-2.37)$ \\
\cline { 2 - 4 } & Severe & 13 & $2.44^{\mathrm{b}}(0.23-4.5)$ \\
\hline \multirow{2}{*}{ Clinical outcome } & Survivors & 26 & $2.002^{\mathrm{a}}(0.001-1.03)$ \\
\cline { 2 - 4 } & Non-survivors & 13 & $2.44^{\mathrm{b}}(0.23-4.5)$ \\
\hline
\end{tabular}

Data are given as median (range); ${ }^{a, b}$ Within a column, values with different superscript letters are significantly $(\mathrm{P}<0.05)$ different for that variable

Table 2. Abnormal cardiac troponin I concentrations in relation with health status and clinical outcome

\begin{tabular}{|l|c|c|c|c|}
\hline \multicolumn{2}{|l|}{ Variable } & $\begin{array}{c}\text { No. of } \\
\text { horses }\end{array}$ & $\begin{array}{c}\text { Number (\%) with abnormal } \\
\text { cardiac troponin I concentrations } \\
(>0.1 \mathrm{ng} / \mathrm{mL})\end{array}$ & \multirow{2}{*}{ Fisher's exact test } \\
\hline \multirow{2}{*}{ Health status } & Healthy & 10 & $0(0)^{\mathrm{a}}$ & \multirow{2}{*}{$\chi^{2}=7.96 ; \mathrm{df}=1 ; \mathrm{P}=0.004$} \\
\cline { 2 - 4 } Clinical outcome & Colic & 39 & $19(48.7)^{\mathrm{b}}$ & \multirow{2}{*}{$\chi^{2}=20.53 ; \mathrm{df}=1 ; \mathrm{P}<0.0001$} \\
\cline { 2 - 5 } & Survivors & 26 & $6(23.1)^{\mathrm{a}}$ & $13(100)^{\mathrm{b}}$ \\
\hline
\end{tabular}

${ }^{\mathrm{a}, \mathrm{b}}$ Within a column, proportions with different superscript letters are significantly different for that variable

Table 3. Vital parameters grouped according to treatment, type of colic, severity of pain and clinical outcome

\begin{tabular}{|l|c|c|c|c|c|}
\hline \multicolumn{2}{|c|}{ Variable } & $\begin{array}{c}\text { No. of } \\
\text { horses }\end{array}$ & $\begin{array}{c}\text { Heart rate } \\
\text { (beats/minute) }\end{array}$ & $\begin{array}{c}\text { Capillary refill time } \\
\text { (seconds) }\end{array}$ & $\begin{array}{c}\text { Respiratory rate } \\
\text { (breaths/minute) }\end{array}$ \\
\hline \multirow{3}{*}{ Health status } & Healthy & 10 & $35^{\mathrm{a}}(29-42)$ & $2^{\mathrm{a}}(1-2)$ & $18^{\mathrm{a}}(14-32)$ \\
\cline { 2 - 6 } & Colic & 39 & $64^{\mathrm{b}}(36-100)$ & $3^{\mathrm{b}}(2-5)$ & $26^{\mathrm{b}}(12-50)$ \\
\hline \multirow{4}{*}{ Type of colic } & Inflammatory & 16 & $66^{\mathrm{a}}(40-92)$ & $3^{\mathrm{a}}(2-4)$ & $38^{\mathrm{a}}(13-48)$ \\
\cline { 2 - 6 } & Impaction & 13 & $72^{\mathrm{a}}(42-86)$ & $2^{\mathrm{a}}(2-5)$ & $28^{\mathrm{ab}}(14-48)$ \\
\cline { 2 - 6 } & Unknown & 10 & $56^{\mathrm{a}}(36-100)$ & $2.5^{\mathrm{a}}(2-5)$ & $20^{\mathrm{b}}(12-50)$ \\
\hline \multirow{3}{*}{ Severity of pain } & Mild & 14 & $53^{\mathrm{a}}(36-74)$ & $2^{\mathrm{a}}(2-3)$ & $20^{\mathrm{a}}(12-42)$ \\
\cline { 2 - 6 } & Moderate & 12 & $62^{\mathrm{ab}}(36-100)$ & $3^{\mathrm{b}}(2-5)$ & $28^{\mathrm{b}}(16-50)$ \\
\cline { 2 - 6 } & Severe & 13 & $74^{\mathrm{b}}(52-92)$ & $3^{\mathrm{b}}(2-5)$ & $36^{\mathrm{b}}(16-48)$ \\
\hline \multirow{3}{*}{$\begin{array}{l}\text { Clinical } \\
\text { outcome }\end{array}$} & Survivors & 26 & $59^{\mathrm{a}}(36-100)$ & $25^{\mathrm{a}}(2-5)$ & $23^{\mathrm{a}}(12-50)$ \\
\cline { 2 - 6 } & Non-survivors & 13 & $72^{\mathrm{b}}(52-92)$ & $3^{\mathrm{b}}(2-4)$ & $36^{\mathrm{a}}(16-48)$ \\
\hline
\end{tabular}

Data are given as median (range); ${ }^{a, b}$ Within a column, values with different superscript letters are significantly $(\mathrm{P}<0.05)$ different for that variable 
Table 4. Spearman's coefficient of correlation \{\displaystyle \rho \} between cardiac troponin I and vital parameters recorded in horses with colic

\begin{tabular}{|l|c|c|c|}
\hline Variable & Cardiac troponin I & Heart rate & Respiration rate \\
\hline Heart rate & $0.57 * * *$ & & \\
\hline Respiration rate & $0.5 * * *$ & $0.43^{* *}$ & $0.39 * *$ \\
\hline Capillary refill time & $0.58^{* * *}$ & $0.57 * * *$ & \\
\hline
\end{tabular}

$* \mathrm{P}<0.05 ; * * \mathrm{P}<0.01 ; * * * \mathrm{P}<0.001$

Table 5. Histological findings of myocardial tissue and associated cardiac troponin I levels in non-survivor horse

\begin{tabular}{|l|c|c|c|}
\hline $\begin{array}{l}\text { Non-survivor } \\
\text { horses }\end{array}$ & Type of colic & Histological findings & $\begin{array}{c}\text { Cardiac troponin } \\
\text { I (ng/mL) }\end{array}$ \\
\hline 1 & Impaction & Multiple focal areas of severe degeneration and necrosis & 1.3 \\
\hline 2 & Inflammatory & Mild degeneration and necrosis & 1.4 \\
\hline 3 & Inflammatory & $\begin{array}{c}\text { Congestion, hemorrhage and moderate degeneration } \\
\text { and necrosis }\end{array}$ & 3.2 \\
\hline 4 & Inflammatory & $\begin{array}{c}\text { Multiple focal areas of moderate to severe degeneration } \\
\text { and necrosis }\end{array}$ & 2.3 \\
\hline
\end{tabular}

The median serum cTnI concentrations according to health status, type of colic, severity of pain, and clinical outcome are shown in Table 1. The cTnI concentration at admission was significantly higher in the colic group compared with the healthy group, where the values were $0.1 \mathrm{ng} / \mathrm{mL}$ versus 0.001 $\mathrm{ng} / \mathrm{mL}(\mathrm{P}=0.004)$, respectively, for the colic and healthy groups. With respect to the type of colic, the median cTnI concentration was significantly $(\mathrm{P}<0.05)$ higher in horses diagnosed with the inflammatory colic $(1.85 \mathrm{ng} / \mathrm{mL})$ compared with horses diagnosed with impaction or an 'unknown' type of colic. Horses with a severe pain had a higher concentration of cTnI (median $2.44 \mathrm{ng} /$ $\mathrm{mL})$ compared with horses showing moderate $(\mathrm{P}=0.002)$ or mild $(\mathrm{P}<0.0001)$ pain. The cTnI concentration was significantly associated with the clinical outcome; the median concentration being higher in the non-survivor group $(2.44 \mathrm{ng} / \mathrm{mL})$ compared with the survivor group $(0.002 \mathrm{ng} / \mathrm{mL}$; $\mathrm{P}<0.0001$ ).

None of the horses in the healthy group $(0 / 10)$, but $48.7 \%$ of the horses in the colic group (19/39) had abnormal cTnI concentrations (defined as $>0.1 \mathrm{ng} / \mathrm{mL}$ ) (Fisher's exact test $\mathrm{P}=0.004$; Table 2 ). Further, there was a significant association observed between an abnormal cTnI concentration at admission and clinical outcome (Fisher's exact test $\mathrm{P}<0.0001)$. All the non-survivor horses $(13 / 13)$ had abnormal cTnI concentrations at admission $(>0.1 \mathrm{ng} / \mathrm{mL})$, whereas, only $23.1 \%(6 / 26)$ of the surviving horses had abnormal cTnI concentrations at admission.

The measured values of vital parameters varied significantly between the healthy and the colic groups (Table 3 ). The median HR was significantly elevated in the colic group compared with the healthy group $(\mathrm{P}<0.0001)$. Similarly, HR was significantly elevated in horses with severe pain compared with those with mild pain $(\mathrm{P}=0.002)$, and horses in the non-survivor group $(\mathrm{P}<0.05)$ compared with those in the survivor group. The CRT was significantly prolonged in horses with colic as compared with healthy horses $(\mathrm{P}<0.001)$; horses with a moderate $(\mathrm{P}<0.05)$ to severe $(\mathrm{P}<0.01)$ pain as compared with those with a mild pain; and in non-survivors as compared with survivors $(\mathrm{P}<0.05)$. The median RR was significantly higher in the colic group compared with the healthy group $(\mathrm{P}<0.05)$, those with inflammatory colic compared with 'unknown' $(\mathrm{P}<0.01)$, and those showing moderate $(\mathrm{P}<0.05)$ to severe $(\mathrm{P}<0.01)$ pain compared with mild pain.

Spearman's coefficients of correlations $\{\backslash$ displaystyle $\backslash$ rho $\}$ between the parameters recorded 
in the horses with colic are presented in Table 4. A positive correlation was found between cTnI, HR, CRT and RR. Moreover, a positive correlation (ranging from $\rho=0.39$ to 0.57 ) was also found between HR, CRT and RR.

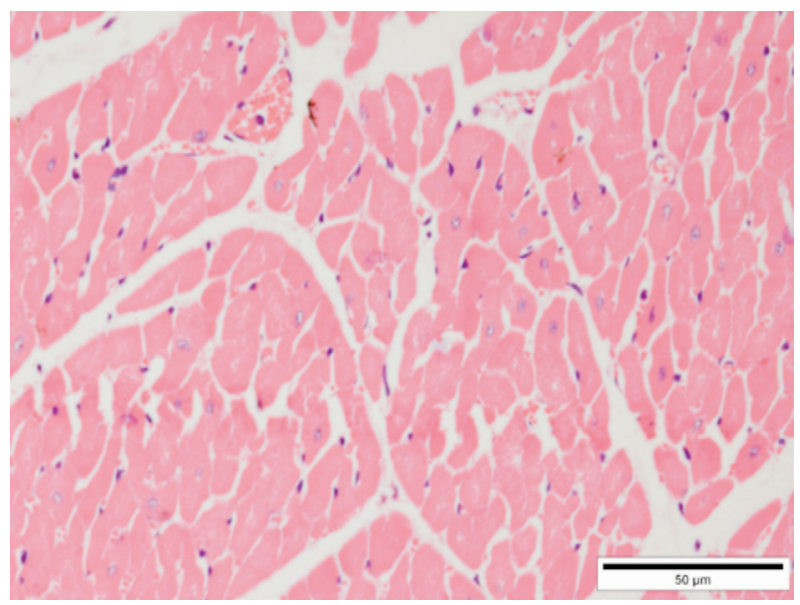

Fig. 1. Photomicrograph of a heart showing congestion, hemorrhage and mild degenerative and necrotic changes in the myocardial fibers. H\&E. (Scale bar $50 \mu \mathrm{m} ; \times 400$ )

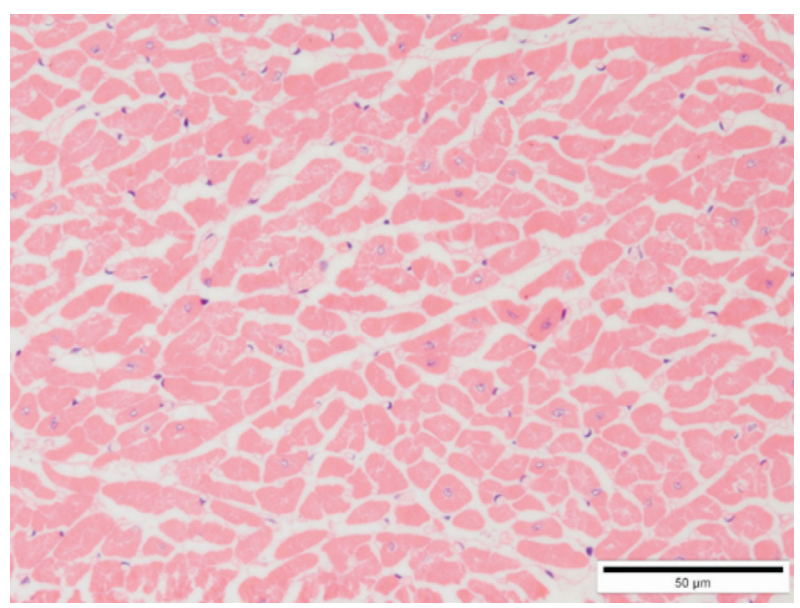

Fig. 3. Photomicrograph of heart showing moderate degenerative and necrotic changes in the myocardial fibers following moderate hypoxic injury. H\&E. (Scale bar $50 \mu \mathrm{m} ; \times 400)$.
Myocardial tissue samples were available for 4 non-survivor horses (three had inflammatory colic and one had impaction colic). Histopathological evaluation of the myocardium revealed a mild to severe degree of myocardial degeneration, along with coagulative necrosis (Table 5 and Figs 1 to 4 ).

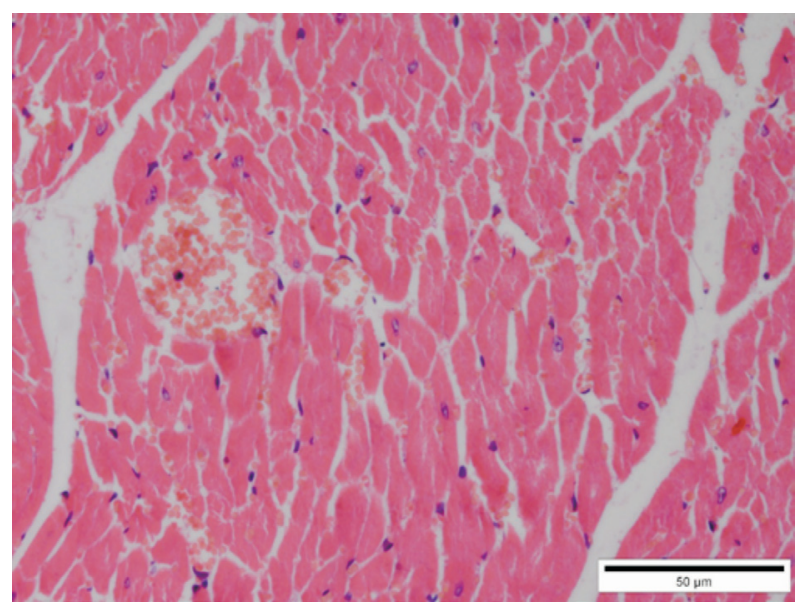

Fig. 2. Photomicrograph of a heart showing congestion, hemorrhage and moderate degenerative and necrotic changes in the myocardial fibers following injury to the blood vessels.H\&E. (Scale bar $50 \mu \mathrm{m} ; \times 400)$.

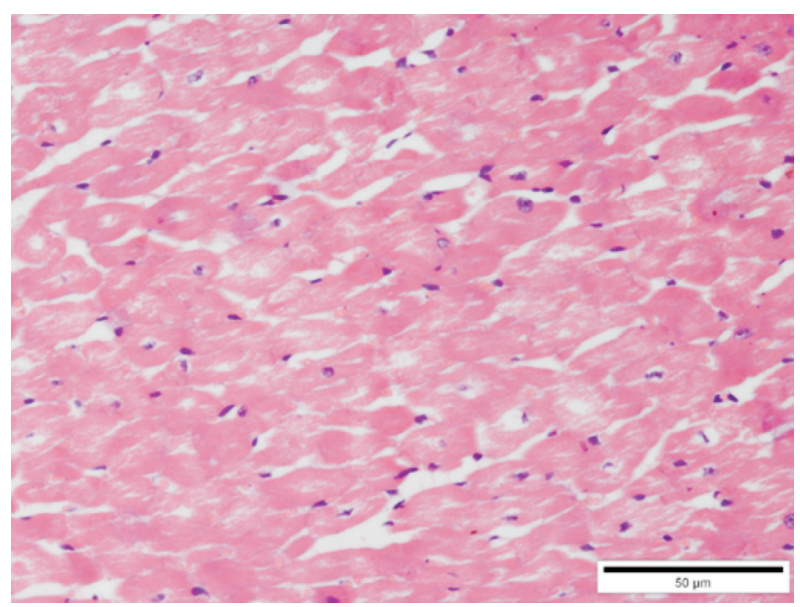

Fig. 4. Photomicrograph of a heart showing severe degenerative and necrotic changes in the myocardial fibers following severe hypoxic injury. H\&E. (Scale bar $50 \mu \mathrm{m} ; \times 400)$. 
All these horses also had severe pain and elevated concentrations of cTnI (range 1.4 to $3.2 \mathrm{ng} / \mathrm{mL}$ ).

\section{Discussion}

The present study describes the high prevalence of cTnI concentrations in horses with colic compared with the healthy controls. All clinically healthy horses in this study had cTnI concentrations comparable with those reported previously (NOSTELL and HAGGSTROM, 2008; SLACK et al., 2012). The healthy group consisted of mainly male horses $(90 \% ; 9 / 10)$ compared with colic group (35.9\% males; 14/39). The comparatively large proportion of males in the healthy group might have had some influence on the cTnI levels, however previous studies could not detect any age, sex, or breed-based differences in the levels of cTnI in clinically healthy horses (KRAUS et al., 2010). In line with previous studies, we also found higher concentrations of $\mathrm{cTnI}$ in horses with colic (NATH et al., 2012b; DIAZ et al., 2014). The increased cTnI levels in horses with colic likely indicate concurrent myocardial cell injury caused by endotoxemia, myocardial hypoxia and sepsis (NATH et al., 2012b; DIAZ et al., 2014). Among these causes, endotoxemia was assumed to be the most probable cause of myocardial cell damage in colic patients. Endotoxins may be absorbed into the systemic circulation from the compromised intestinal mucosa in horses suffering from acute GIT disease (KING and GERRING, 1988; NATH et al., 2012b; DIAZ et al., 2014). Increased plasma cTnI concentrations and cardiac arrhythmias have been detected in horses with experimentally induced endotoxemia (NOSTELL et al., 2012). Studies involving dogs and humans have also demonstrated marked cardiovascular disarrangements due to the inflammatory response induced by endotoxins, leading to hypotension, cardiac dysfunction, multiple organ failure and death (NATANSON et al., 1989; SUFFREDINI et al., 1989). Further, $48.7 \%$ of the colic patients in this study had abnormal levels of cTnI $(>0.1 \mathrm{ng} / \mathrm{mL})$ at the time of admission; the proportion observed was more than that reported earlier (34.2\%) (DIAZ et al., 2014). This could possibly be due to the duration of clinical signs and the severity of disease at the time of admission. In humans, cTnI levels begin to increase from 2-6 hours after myocardial injury, reaching their maximum at 18-24 hours (JAFFE et al., 2006). In clinical workup, it is suggested that cTnI is estimated first at admission, and again 6-9 hours later in humans with suspected myocardial injury (BABUIN and JAFFE, 2005). In horses, elevated cTnI secondary to strenuous exercise, colic and monensin toxicoses suggest a similar rise 4-6 hours after the injury, with a peak from 6-48 hours (HALLOWELL and BOWEN, 2007; NOSTELL and HAGGSTROM, 2008). In the present study, all the enrolled horses had developed acute colic (i.e. presented to the hospital within 12 hours of onset of clinical signs), out of which $64 \%$ had moderate to severe types of colic.

In the present study, an abnormal cTnI concentration at admission was significantly associated with a more severe type of colic and an unfavorable clinical outcome. Among the 16 horses with inflammatory colic, eight had severe pain; five had moderate pain; three had strangulating lesions; two had enterocolitis; and one had peritonitis. The horses with strangulating lesions had more elevated cTnI levels $(2.65,4.25$ and $4.5 \mathrm{ng} / \mathrm{mL}$, respectively). Of the 13 non-survivor cases, nine had inflammatory colic; and 12 had severe pain. These findings were similar to a previous study in horses with acute gastrointestinal disease, in which the proportion of horses with elevated cTnI concentrations was significantly greater among horses with strangulating or inflammatory colic compared with healthy horses (NATH et al., $2012 b$ ). The prognostic role of cTnI in predicting survivability in equine colic patients has been demonstrated earlier, and this revealed a significant association between non-survivability and higher cTnI concentrations (NATH et al., 2012b; DIAZ et al., 2014). In another study involving horses undergoing emergency abdominal surgery, it was observed that horses with higher $\mathrm{cTnI}$ concentrations $(>0.06 \mathrm{ng} / \mathrm{mL})$ at admission were 38 times more likely to die compared to horses with normal cTnI (RADCLIFFE et al., 2012). These findings may reflect myocardial cell damage in horses with severe abdominal disease, most likely occurring from increases in myocardial damaging factors as 
seen in septic human patients (SCHMITTINGER et al., 2010).

In this study, clinical variables were significantly elevated in horses with colic and those showing severe pain. Also, elevated HR and CRT appeared to be associated with unfavorable clinical outcome. The present findings are in line with previous studies evaluating clinical variables in horses with colic (ILHER et al., 2004; BRYAN et al., 2009; WORMSTRAND et al., 2014;). The conjunctival mucus membrane was congested in $71.8 \%$ of the affected horses, which could be due to concurrent development of toxemia, septicemia or endotoxemia (BRYAN et al., 2009). Of the colic patients, $61.5 \%$ had CRT $\geq 3 \mathrm{sec}$ at the time of admission. Congested mucous membranes with prolonged CRT could be associated with hypovolemia, peripheral hypo-perfusion, and poor prognosis (BRYAN et al., 2009). Higher RR in horses with colic could be due to the pain, excitation, increased muscular activity, or over-distension of the stomach and small intestines that causes compression of the lungs (SMITH, 2000). Derangements of the parameters assessing cardiovascular system, such as HR, mucous membrane color and CRT, probably indicate the severity of gastrointestinal disease and, therefore, play an important role in evaluating the clinical outcome of equine colic patients (ILHER et al., 2004; SUTTON et al., 2009; WORMSTRAND et al., 2014). A positive correlation between these parameters and cTnI further supported our findings that higher cTnI levels could be used to predict the severity of gastrointestinal disease in horses.

In the present study, histopathological examination of myocardial muscles demonstrated a varying degree of myocardial degeneration and necrosis. Three of these samples belonged to horses with inflammatory colic; and all four had elevated cTnI levels. There is paucity of literature depicting histopathological changes in myocardial muscles in equine colic patients. One case report described an association between increased cTnI level and the presence of microscopically visible myocardial infarction in a horse with large intestinal meteorism and secondary proximal enteritis (SABEV and DINEV, 2012). In another study, acute subendocardial and epicardial hemorrhages were demonstrated in only one out of the five horses that died due to colic and having elevated cTnI concentrations at admission (DIAZ et al., 2014). Although histopathological examination could be possible in four cases, these findings suggests that horses with severe colic and elevated cTnI concentrations probably have some degree of myocardial cell degeneration and necrosis.

The present study is limited by the small sample size. Also, the failure to perform a complete histological examination of the myocardium in all the non-survivor cases limited the ability to detect myocardial damage and to correlate the histological findings with cTnI concentrations.

\section{Conclusions}

In conclusion, horses with severe colic and elevated cTnI concentrations were more likely to develop myocardial injury, as revealed by the presence of myocardial degeneration and necrosis on histopathological evaluation. Further, these horses were more likely to have poor clinical outcome in this study.

\section{Conflicts of interest}

The authors do not have any conflicts of interest to declare.

\section{References}

ADAMS, J. E. ( $\left.3^{\text {ri }}\right)$, G, S. BODOR, V. G. DAVILA-ROMAN, J. A. DELMEZ, F. S. APPLE, J. H. LADENSON (1993): Cardiac troponin I. A marker with high specificity for cardiac injury. Circulation 88, 101-106.

DOI: 10.1161/01.cir.88.1.101

ALSAAD, K. M., A. A. NORI (2010): Clinical, hematological and biochemical studies of colic syndrome in draught horses in Mosul. Proceedings of the $14^{\text {th }}$ Scientific Conference. Faculty of Veterinary Medicine, Assiut University, Egypt, pp. 169-189.

BABUIN, L., A. JAFFE (2005): Troponin: The biomarker of choice for the detection of cardiac injury. Can. Med. Assoc. J. 173, 1191-1202.

DOI: $10.1503 / \mathrm{cmaj} / 051291$

BRYAN, J., F. DAVID, V. DUGGAN (2009): Investigation of acute colic in the adult horse. Irish Vet. J. 62, 541-547.

COLlinson, P. O., F. G. BOA, D. C. GAZE (2001): Measurement of cardiac troponins. Ann. Clin. Biochem. 38, 423-449.

DOI: $10.1177 / 000456320103800501$ 
CURTIS, L., J. H. BURFORD, J. S. M. THOMAS, M. L. CURRAN, T. C. BAYES, G. C. W. ENGLAND (2015): Prospective study of the primary evaluation of 1016 horses with clinical signs of abdominal pain by veterinary practitioners, and the differentiation of critical and noncritical cases. Acta. Vet. Scand. 57.

DOI: $10.1186 /$ s13028-015-0160-9

DIANA, A., C. GUGLIELMINI, D. CANDINI, M. PIETRA, M. CIPONE (2007): Cardiac arrhythmias associated with piroplasmosis in the horse: A case report. Vet. J. 174, 193195.

DOI: 10.1016/j.tvj1.2006.04.003

DIAZ, O. S. M., M. M. DURANDO, E. K. BIRKS, V. B. REEF (2014): Cardiac troponin I concentrations in horses with colic. J. Am. Vet. Med. Assoc. 245, 118-125.

DOI: 10.2460/javma.245.1.118.

EGENVALL, A., J. C. PENELL, B. N. BONNETT, P. OLSON, J. PRINGLE (2006): Mortality of Swedish horses with complete life insurance between 1997 and 2000: Variations with sex, age, breed and diagnosis. Vet. Rec. 158, 397-406. DOI: $10.1136 /$ vr.158.12.397.

FENNELL, L., S. CHURCH, D. TYRELL, G. FORBES, J. CHARLES, C. MCCOWAN, C. SAVAGE (2009): Doubleoutlet right ventricle in a 10-month-old Friesian filly. Aust. Vet. J. 87, 204-209.

DOI: $10.1111 /$ j.1751-0813.2009.00424.X

HALLOWELL, G. D., I. M. BOWEN (2007): Cardiac troponin I in equine surgical colic patients: Myocardial damage due to endotoxaemia or hypoperfusion? J. Vet. Intern. Med. 21, 604.

IHLER, C. F., J. L. VENGER, E. SKJERVE (2004): Evaluation of clinical and laboratory variables as prognostic indicators in hospitalised gastrointestinal colic horses. Acta Vet Scand. 45, 109-118.

DOI: $10.1186 / 1751-0147-45-109$

JAFFE, A. S., L. BABUIN, F. S. APPLE (2006): Biomarkers in acute cardiac disease: the present and the future. J. Am. Coll. Cardiol. 48, 1-11.

DOI: 10.1016/j.jacc.2006.02.056

KING, J.N., E. L. GERRING(1988): Detection of endotoxaemia in cases of equine colic. Vet. Rec. 123, 269-271. DOI: $10.1136 /$ vr.123.10.269

KRAUS, M., S. A. JESTY, A. R. GELZER, N. G. DUCHARME, H. MOHAMMED, L. M. MITCHELL, L. V. SODERHOLM, T. J. DIVERS (2010): Measurement of plasma cardiac troponin I concentration by use of a pointof-care analyzer in clinically normal horses and horses with experimentally induced cardiac disease. Am. J. Vet. Res. 71, 55-59.

DOI: $10.2460 /$ ajvr.71.1.55

NATANSON, C., P. EICHENHOLZ, R. DANNER, P. Q. EICHACKER, W. D. HOFFMAN, G. C. KUO, S. M. BANKS, T. J. MACVITTIE, J. E. PARRILLO (1989):
Endotoxin and tumor necrosis factor challenges in dogs simulate the cardiovascular profile of human septic shock. J. Exp. Med. 169, 823-832.

DOI: $10.1084 /$ jem.169.3.823.

NATH, L. C., G. A. ANDERSON, K. W. HINCHCLIFF, C. J. SAVAGE (2012a): Serum cardiac troponin I concentrations in horses with cardiac disease. Aust. Vet. J. 90, 351-357.

DOI: 10.1111/j.1751-0813.2012.00970.x.

NATH, L. C., G. A. NDERSON, K. W. HINCHCLIFF, C. J. SAVAGE (2012b): Clinicopathologic evidence of myocardial injury in horses with acute abdominal disease. J. Am. Vet. Med. Assoc. 241, 1202-1208.

DOI: $10.2460 /$ javma.241.9.1202.

NOSTELL, K., J. BROJER, K. HOGLUND, A. EDNER, J. HÄGGSTRÖM (2012): Cardiac troponin I and the occurrence of cardiac arrhythmias in horses with experimentally induced endotoxaemia. Vet. J. 192, 171-175. DOI: 10.1016/j.tvj1.2011.05.013.

NOSTELL, K., J. HAGGSTROM (2008): Resting concentrations of cardiac troponin I in fit horses and effect of racing. J. Vet. Cardiol. 10, 105-109.

DOI: 10.1016/j.jvc.2008.10.001.

RADCLIFFE, R. M., T. J. DIVERS, D. J. FLETCHER, H. MOHAMMED, M. S. KRAUS (2012): Evaluation of L-lactate and cardiac troponin I in horses undergoing emergency abdominal surgery. J. Vet. Emerg. Crit. Care. 22, 313-319.

DOI: 10.1111/j.1476-4431.2012.00744.x.

RAJAPPA, M., A. SHARMA (2005): Biomarkers of cardiac injury: An update. Angiol.56, 677-691.

DOI: $10.1177 / 000331970505600605$.

RANI, P., R. S. SINGH, S. SINGH, B. K. BANSAL (2018): A study on clinico-biochemical evaluation in equine colic patients. J. Anim. Res. 8, 93-99.

RISHNIW, M., K. W. SIMPSON (2005): Cloning and sequencing of equine cardiac troponin I and confirmation of its usefulness as a target analyte for commercial troponin I analyzers. J. Vet. Diagn. Invest. 17, 582-584.

DOI: $10.1177 / 104063870501700611$.

ROBERTSON, S. A., L. C. SANCHEZ (2010): Treatment of visceral pain in horses. Vet. Cl. North Am. 26, 603-617. DOI: 10.1016/j.cveq.2010.08.002.

ROSSI, T., W. PYLE, M. MAXIE, D. PEARL, P. PHYSICKSHEARD (2014): Troponin assays in the assessment of the equine myocardium. Equine Vet. J. 46, 270-275. DOI: $10.1111 /$ evj.12209.

SABEV, S., I. DINEV (2012): Myocardial infarction in a horse with colic - Clinical, laboratory and pathomorphological findings. Bulg. J. Vet. Med. 15, 287-293.

SCHMITTINGER, C. A., B. WURZINGER, M. DEUTINGER, C. WOHLMUTH, H. KNOTZER, C. TORGERSEN, M. W. DÜNSER, W. R. HASIBEDER (2010): How to protect the 
heart in septic shock: a hypothesis on the pathophysiology and treatment of septic heart failure. Med. Hypotheses 74, 460-465.

DOI: $10.1016 /$ j.mehy.2009.10.012

SENIOR, J. M., C. J. PROUDMAN, M. LEUWER, S. D. CARTER (2011): Plasma endotoxin in horses presented to an equine referral hospital: Correlation to selected clinical parameters and outcomes. Equine Vet. J. 43, 585-591.

DOI: 10.1111/j.2042-3306.2010.00328.x

SLACK, J., R. C. BOSTON, L. SOMA, V. B. REEF (2012): Cardiac Troponin I in racing Standardbreds. J. Vet. Inter. Med. 26, 1202-1208.

DOI: $10.1111 / \mathrm{j} .1939-1676.2012 .00969 . \mathrm{x}$

SMITH, B. P. (2000): Large Animal Internal Medicine. $3^{\text {rd }}$ ed., Mosby publishing, Portland, Oregon, pp. 1513-1518.

SUFFREDINI, A. F., R. E. FROMM, M. M. PARKER, M. BRENNER, J. A. KOVACS, R. A. WESLEY, J. E. PARRILLO (1989): The cardiovascular response of normal humans to the administration of endotoxin. N. Engl. J. Med. 321, 280-287.

DOI: 10.1056/NEJM198908033210503
SUTTON, G. A., R. ERTZMAN-GINSBRG, A. STEIMAN, J. MILGRAM (2009): Initial investigation of mortality rates and prognostic indicators in horses with colic in Israel: A retrospective study. Equine Vet. J. 41, 482-486.

DOI: $10.2746 / 042516409 \times 391060$

VAN LOON, J. P. A. M., W. BACK, L. J. HELLEBREKERS, P. R. VAN WEEREN (2010): Application of a composite pain scale to objectively monitor horses with somatic and visceral pain under hospital conditions. J. Equine Vet. Sci. 30, 641-649.

DOI: 10.1016/j.jevs.2010.09.011

WORMSTRAND, B. H., C. F. IHLER, R. DIESEN, R. I. KRONTVEIT (2014): Surgical treatment of equine colic-a retrospective study of 297 surgeries in Norway 2005-2011. Acta Vet. Scand. 56, 38.

DOI: $10.1186 / 1751-0147-56-38$

Received: 18 April 2019

Accepted: 12 November 2021

RANI, P., R. S. SINGH, S. SINGH, K GUPTA: Dokaz oštećenja miokarda u konja s kolikom. Vet. arhiv 91, 565-574, 2021.

\section{SAŽETAK}

U konja s kolikom čest je razvoj endotoksemije povezane s gastrointestinalnim ozljedama. Takvi bolesnici vjerojatno će razviti kardiovaskularne komplikacije, uključujući oštećenje miokarda. Manji broj istraživanja analizirao je prevalenciju oštećenja miokarda u konja s kolikama. Biomarkeri, kao što je srčani troponin I (cTnI), često su korišteni u humanoj i veterinarskoj medicini za dijagnosticiranje oštećenja miokarda. Cilj ovog istraživanja bio je mjerenjem koncentracije cTnI u serumu analizirati pojavu oštećenja miokarda u konja s kolikom. U istraživanje su uključeni i uginuli konji od kojih su uzeti uzorci tkiva miokarda i podvrgnuti histopatološkoj procjeni. Koncentracija cTnI u serumu mjerena je u 10 zdravih konja i 39 konja s kolikom. Analizirana je povezanost koncentacije cTnI s varijablama zdravstveni status (zdravi i konji s kolikom), vrsta kolike (upalna, zastojna, nepoznata), jačina abdominalne boli (blaga, umjerena i teška) i klinički ishod (preživjeli do otpuštanja i nepreživjeli). U usporedbi sa zdravim konjima, koncentracije cTnI bile su znakovito povišene u konja s kolikom $(\mathrm{P}=0,004)$. U konja s kolikom, abnormalna koncentracija cTnI bila je znakovito povezana s upalnim tipom kolike $(\mathrm{P}<0,05)$, teškom boli u abdomenu $(\mathrm{P}<0,01)$ i nepreživljavanjem kao kliničkim ishodom $(\mathrm{P}<0,0001)$. Nadalje, histopatološkom procjenom mišića miokarda utvrđeni su različiti stupanjevi degeneracije i nekroze. Ovo je istraživanje pokazalo da su konji s teškom kolikom i povišenim razinama cTnI skloniji razvoju oštećenja miokarda. Povišene razine cTnI mogu također ukazivati na slabu prognozu u konja s teškom kolikom.

Ključne riječi: kolika; konj; miokard; srčani troponin I; histopatologija 